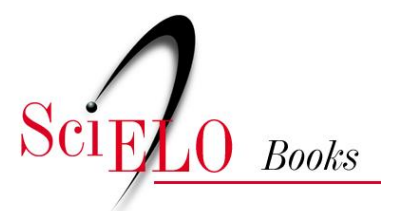

\title{
Guerras flamengas
}

\author{
Capistrano de Abreu
}

\section{SciELO Books / SciELO Livros / SciELO Libros}

ABREU, C. Guerras flamengas. In: Capítulos da história colonial [online]. Rio de Janeiro: Centro Edelstein de Pesquisa Social, 2009. pp. 66-88. ISBN: 978-85-7982-071-7.

https://doi.org/10.7476/9788579820717.0008.

\section{() pobuntiv}

This work is free of known copyright restrictions. http://creativecommons.org/publicdomain/mark/1.0/

Este trabalho está livre de restrições de direito de autor e/ou de direitos conexos conhecidas.

http://creativecommons.org/publicdomain/mark/1.0/

Esta obra está libre de restricciones conocidas de derechos autorales. http://creativecommons.org/publicdomain/mark/1.0/ 


\section{GUERRAS FLAMENGAS}

As relações entre Portugal e Flandres, iniciadas desde a idade média, continuaram ainda depois de descoberto o caminho marítimo das Índias e achado e colonizado o Brasil. Iam os flamengos a Lisboa adquirir as drogas e gêneros exóticos, apenas desembarcados, e retalhavam-nos pela vasta clientela do Norte e Ocidente da Europa, poupando canseiras e garantindo lucros imediatos aos portugueses; estes, além do dinheiro de contado, proviam-se, graças aos seus fiéis fregueses, de cereais, peixe salgado, objetos de metal, aparelhos náuticos, fazendas finas.

Modificou-se esta situação vantajosa para ambas as partes quando a monarquia espanhola abarcou a península inteira e os inimigos de Castela passaram a ser os de Portugal. Em 1585, Filipe II mandou confiscar os navios flamengos ancorados em seus portos, aprisionando-lhes as tripulações. O mesmo se fez em 1590, 1595 e 1599.

Dificilmente se conceberia mais terrível golpe contra um povo que do comércio marítimo auferia o melhor de suas riquezas, base de uma independência comprada a poder de sangue. Depois de tanto heroísmo teria de sujeitar-se ao domínio do Meio-Dia? Para escapar a estes apuros brotaram os mais desencontrados alvitres: procurar pelo Norte da Ásia outro caminho marítimo para a China e Índia; transferir a atividade comercial para o Mediterrâneo; apossar-se do estreito de Magalhães. Tudo isto se tentou, de tudo se tirou resultado negativo. Por que não se afrontaria o cabo da Boa Esperança, a buscar os gêneros do Oriente nos próprios lugares de sua procedência?

Em 1595, mercadores de Amsterdam arriscaram a primeira viagem ao oceano Índico, viagem demorada, de pouco proveito imediato, mas fecundíssima em consequências, pois logrou a certeza da fragilidade do domínio peninsular naquelas regiões alongadas. Da mesma cidade partiram outros navios em maio de 1598, terceira expedição em abril, quarta em dezembro de 1599. Em várias províncias surgem negociantes arrojados, improvisam-se companhias opulentas, ávidas de despojos e aventuras no amplo teatro que agora se abria. A emulação salutar ameaçava degenerar em rivalidade perniciosa. Homens sagazes anteviram o perigo; intervieram os Estados Gerais, e por meio de concessões e privilégios conciliaram as pretensões divergentes, fundando a Companhia das Índias Orientais no começo de 1602

A trégua de doze anos, assentada em 1609 entre os Países Baixos e a Espanha, em nada interrompeu a carreira aventurosa da Companhia, que com poucos anos de existência se impôs aos príncipes indígenas, repeliu os ingleses, derrocou a aparatosa fábrica luso-hispânica, monopolizou o trato das especiarias, distribuiu dividendos enormes, prestou serviços inestimáveis ao governo das Províncias Unidas.

Na constância do armistício sazonou a ideia de uma companhia das Índias ocidentais, análoga à outra nos intuitos e na organização, que obteve foral a 3 de junho de 1621. Seu capital seria de sete milhões, cento e tantos mil florins; o privilégio duraria vinte e quatro anos; constaria de cinco câmaras, representando os acionistas de Amsterdam, Zelândia, cidades do Maas, o distrito do Norte e a Frísia; os diretores, em número de dezenove, funcionariam alternadamente em Amsterdam e Middelburg. A esfera privilegiada seria, na África, do trópico de Câncer ao cabo da Boa Esperança; ao Ocidente, desde Terra-Nova, no Atlântico, até o estreito de Anian no Pacífico.

Os Estados Gerais concederam-lhe faculdade de construir fortes na região outorgada, contrair tratados com os príncipes e povos indígenas, nomear autoridades e funcionários; obrigaram-se a subvencioná-la, para ficar com direito a certa parte dos dividendos; forneceriam soldados e naus de guerra em condições especificadas. Em suma, deixando de parte diferenças patentes, a Companhia das Índias Ocidentais filiou-se ao sistema dos donatários iniciados por d. João III.

A Companhia deixou sinais de sua passagem no território africano, nas costas dos Estados Unidos, nas Antilhas, no Brasil, no Chile. A nós só importam os feitos ocorridos em nossa terra.

Sua criação foi acolhida com frieza na Holanda; ainda em 1622 não estava subscrito um quinto sequer do capital que só ficou integralizado depois de obtidas vantagens suplementares, entre outras, o monopólio de exportação do sal brasileiro, em 1624.

Desde 1623 começou a preparar uma expedição contra a Bahia. Vinte e três navios e três iates com quinhentas bocas de fogo, tripulados por mil e seiscentos marinheiros, foram aos poucos se reunindo em S. Vicente do 
Cabo-Verde nos fins deste e no começo do seguinte ano. A 26 de março partiram rumo de SW, a 4 de maio descobriram costa do Brasil, a 8 surgiram diante da baía de Todos-os-Santos e foram vistos de terra.

Governava a cidade do Salvador e o Brasil em geral Diogo de Mendonça Furtado. Tinham-lhe chegado notícias do perigo iminente e procurara prevenir-se.

Sobejavam-lhe coragem e boa vontade, faltava-lhe tudo o mais: as fortalezas já arruinadas umas, outras por acabar, a barra larga e franca, acessível sem prático às maiores embarcações a qualquer hora do dia e da noite, a guarnição reduzida e imbele, a população trépida, prestes a fugir mal avistava qualquer vela suspeita, não encerravam elementos de resistência eficaz. Acresciam dissenções entre o governador e o bispo e, como de costume, entre uma e outra metade do povo, sempre ávido de questões entre os potentados.

A 9 de maio a armada enfiou a barra e dirigiu o ataque por terra e por mar. Na ponta de S. Antônio, à entrada, desembarcaram mil e duzentos soldados e duzentos marinheiros: e à sua aproximação a força dos colonos postada retirou-se às carreiras, semeando o pânico. Dos fortes houve alguns disparos, alguns navios pareceram dispostos a resistir; quando o inimigo se aproximou, recorreu-se ao incêndio para evitar fossem cair-lhe às mãos os ricos carregamentos de açúcar, pau-brasil, fumo e peles. Mesmo assim, muitos foram salvos.

À noite, bispo, eclesiástico, os moradores que puderam abandonaram a cidade. Ao amanhecer, além de escravos e gente baixa sem nada a perder, encontravam-se apenas o governador e alguns fiéis na cidade deserta. Com facilidade os invasores prenderam-nos e mais tarde mandaram-nos para a Holanda. Os fugitivos acomodaram-se como puderam em engenhos próximos, aldeias de índios, debaixo de árvores, ao céu aberto. Quantas privações passaram e como foi difícil sustentar e conter esta multidão, pode-se bem imaginar. Ainda depois de reunidos em arraial e estabelecida certa ordem, a empresa nada tinha de fácil.

As vias de sucessão, então abertas, nomeavam para substituto do governador a Matias de Albuquerque Coelho. Estava em Pernambuco, capitania hereditária de seu irmão, em cujo nome governava, a mais de cem léguas de distância. Antes que recebesse a notícia e tomasse qualquer providência, perder-se-ia tempo, um tempo precioso. Elegeu-se, pois, capitão-mor interino o desembargador Antão de Mesquita; dentro em pouco, por motivos pouco conhecidos ainda, ficou sendo governador de fato o bispo dom Marcos Teixeira.

Uma só coisa havia a fazer com os recursos da terra: cercar o invasor dentro da cidade, impedindo que penetrasse pelas cercanias para renovar provisões, impossibilitando as adesões das classes baixas, indiferentes à mudança do senhor, pois o cativeiro prosseguiria invariável. A falta de armamentos apropriados, a escassez e por fim a carência completa de pólvora limitaram as operações à arma branca; à flecha, ao combate singular, à tocaia; as companhias de emboscadas, em número de trinta, composta cada uma de poucas dezenas de combatentes, pelo subitâneo da aparição nos lugares mais diversos, mantiveram o inimigo sobressaltado; a multiplicidade dos assaltos, quase sempre coroados de êxito, alimentava a coragem e fortaleceu o espírito patriótico.

Entretanto chegava a Pernambuco a notícia de ser tomada a cidade. Matias de Albuquerque, informa um contemporâneo, nem de dia, nem de noite, se poupava ao trabalho. Não quis nunca andar em rede, como no Brasil se costuma, senão a cavalo ou em barcos, e quando nestes entrava não se assentava, mas em pé ia ele próprio governando. Tinha grande memória e conhecimento dos homens, ainda que uma só vez os visse, e ainda dos navios que uma vez vinham àquele porto. Esta atividade fervorosa, unida a uma energia indomável, ver-se-á melhor no decurso da narrativa.

Por sua ordem partiu logo Francisco Nunes Marinho em dois caravelões, com pólvora, munições de fogo e de boca e trinta soldados. Trataram-no mal as tormentas; de vergas e mastros quebrados, arribou a Sergipe; mas já em começos de setembro juntava-se à gente do arraial. Sob o seu governo as guerrilhas avançaram para o interior da Bahia até Itapagipe, para o lado da barra até a ponta de Santo Antônio; novas e mais fortes trincheiras foram levantadas. Dois barcos, um no Itapoã, e outro no morro de S. Paulo, vigiavam o mar, avisando os navios portugueses que evitassem o porto, para não serem aprisionados como já o haviam sido outros.

Pequenos socorros do Reino iam chegando a Pernambuco e Matias de Albuquerque reforçava-os, e encaminhava-os sem perda de tempo. 
Graças a ele, d. Francisco de Moura, vindo com o título de capitão-mor do recôncavo, conduzindo três caravelas, partiu de Recife depois de demora de oito dias, levando seis caravelões, oitenta mil cruzados de provimentos novos. A 3 de dezembro troava a artilharia no acampamento, e os holandeses, curiosos da novidade, só então souberam como ao bispo, poucos dias antes de falecer, sucedera Francisco de Moura, antigo governador do Cabo Verde.

$\mathrm{Na}$ cidade conquistada as coisas corriam mal para o inimigo. Johannes van Dorth, governador pela Companhia, foi morto numa emboscada. Albert Schout, seu sucessor, tratou das fortificações, mas em festas e banquetes apanhou uma enfermidade, que em poucos dias o levou. Willem Schout, seu irmão, mostrou-se alheio às responsabilidades do cargo.

Contudo a situação poderia manter-se indefinidamente, máxime dominando o oceano a armada da Companhia; tratava-se de saber quem receberia primeiros socorros de além-mar. Por uma felicidade nunca mais repetida foram os nossos. A corte espanhola, geralmente desatenta e inerte, desta vez sentiu a gravidade do golpe; o rei, ou antes Olivares, seu ministro onipotente, percebeu a ameaça implícita contra o México e o Peru; cartas régias do próprio punho, procissões, novenas, excitaram o espírito público; a nobreza da Espanha e a de Portugal alistaram-se com entusiasmo na cruzada contra o hereje rebelde; fidalgos e prelados fizeram largos donativos, fretaram navios, custearam companhias; as armadas de Portugal, do Oceano, do Estreito, de Biscaia, das Quatro-Vilas, de Nápoles, somaram cinquenta e dois navios de guerra; mais de doze mil homens d'armas embarcaram para o Novo Mundo. Comandante geral de todas as forças era d. Fadrique de Toledo.

A armada chegou à Bahia sábado da aleluia, 29 de março de 1625, no mesmo dia que aí aportara Tomé de Sousa, o fundador da cidade, setenta e seis anos antes. Formou em meia-lua, da ponta de Santo Antônio à de Itapagipe, fechando a saída aos navios holandeses ancorados.

A tropa desembarcou em Santo Antônio e tomou logo posição em São Bento, Palmeiras, Carmo e outros morros. A 2 de abril travou-se o primeiro combate, seguido de outros. O cerco apertou-se por terra e por mar. Os sitiados foram obrigados a render-se. A 30 de abril assinava-se a capitulação. A 1 de maio abriram-se as portas e entrou o exército vencedor. A 26 apareceu na barra o socorro holandês, trinta e quatro naus, comandadas por Boudewiyn Hendrikszoon. Ambas as armadas evitaram porém travar novos combates e os holandeses foram piratear em outras regiões mais indefesas.

Nos anos seguintes a Companhia mandou diversos navios que estiveram no Brasil e em outras partes da África e da América, devastando e saqueando. Seu triunfo mais completo foi a tomada da frota espanhola, junto à costa de Cuba, por Pieter Heyn, em setembro de 1628. De uma só vez entraram-lhe para os cofres mais de quatorze milhões, o duplo do capital inicial; os dividendos subiram a 50\%. Com as finanças restauradas, preparou nova expedição ao Brasil; agora preferiu Pernambuco para ponto de investida.

A 26 de dezembro de 1629 zarpou de S. Vicente uma armada de cinquenta e dois navios e iates, e treze chalupas, poderosamente artilhados, com três mil setecentos e oitenta marinheiros, três mil e quinhentos soldados; a 3 de fevereiro de 1630 avistou o Brasil; a 13 chegou em frente a Olinda; no dia seguinte abriu o ataque.

Comandava a capitania Matias de Albuquerque, neto do velho Duarte Coelho, irmão do quarto donatário. Com as notícias da próxima invasão, partira de Lisboa a 12 de agosto de 1629, trazendo vinte e sete soldados e alguma munição em uma caravela. Chegou ao Recife a 18 de outubro, e entregou-se com todo o devotamento à obra desesperada.

As fortalezas estavam arruinadas como na Bahia. Se a barra do Recife não oferecia as comodidades da baía de Todos-os-Santos e não custaria cegá-la, em compensação dava fácil desembarque desde PauAmarelo ao Norte, até Candelária ao Sul, na extensão de sete léguas. Poderse-ia ao menos contar com o sangue frio da população?

O inimigo dividiu a ofensiva por três pontos. O grosso da armada, comandada pelo almirante Loncq, investiu a barra, e estacou por achá-la obstruída. Outro troço dirigiu-se diretamente para Olinda. Com três mil homens o coronel Diedrich van Weerdenburgh aproou primeiro para o rio Tapado, depois para o Pau-Amarelo, mais ao Norte, onde desembarcou na tarde de 15 de fevereiro. Na manhã seguinte, formado em três colunas, marchou para o Sul; as pequenas resistências esporádicas da nossa gente cederam à tropa numerosa e às embarcações de que saltara, que navegavam a pequena distância, apoiando-lhes os movimentos. 
À entrada da vila alguns militares sacrificaram-se nobremente. O troço da armada mandado de véspera contra ela apossou-se das trincheiras da praia. Quando anoiteceu, o pavilhão batavo flutuava sobre a antiga Marim.

A população abandonou a vila e procurou abrigo nos matos e nos engenhos. A soldadesca invasora entregou-se ao saque e à embriaguez. Matias de Albuquerque mandou tocar fogo nos navios e nos armazéns para ao menos arrancar das garras da Companhia o fruto do trabalho amargamente suado. A povoação de Recife, iluminada pelos clarões de incêndio, converteu-se um montão de ruínas. Defendiam-na ainda dois fortes: um no istmo que vai para Olinda, outro no próprio recife. Reforçouos o general com gente e munições, e mais de um ataque foi repelido com vantagem; mas a 2 de março o de S. Jorge, velho, capaz só de resistir a ataques de índios, capitulou, e o de São Francisco da barra seguiu-lhe o exemplo. Só então a armada holandesa entrou no porto.

Durante este tempo Matias de Albuquerque trazia sempre inquieto o inimigo. Entregue aos próprios recursos não lograria desalojá-lo, mas tirava-lhe o sossego, diminuia-lhe a confiança, reduzia-lhe o número, impedia-lhe as comunicações com a gente da terra e nesta substituía o soçobro do primeiro momento pelo desejo de lutar e desprezo de morrer: a dominação holandesa era um fato; não era, nunca seria um fato consumado.

A 4 de março o general escolheu uma eminência quase a uma légua do Recife e de Olinda, próximo do rio Capibaribe e ainda mais do riacho Parnamirim, ponto de boa água e lenha. Com vinte pessoas começou a fortificação, plantando quatro peças. Deu à obra o nome de arraial do BomJesus. Pouco a pouco foram chegando aderentes: aventureiros, senhores de engenho sós ou seguidos de escravos, índios aldeados. Entre estes entra logo a aparecer com um brilho que irá sempre crescendo Antônio Camarão, chefe petiguar de vinte e oito anos de idade, o mais fiel e preciso dos auxiliares. Dez dias mais tarde o arraial já repelia com grandes perdas um assalto do inimigo. Será esta a sua história perene durante os cinco anos seguintes.

Como contar os sucessos desta guerra sem precedentes? Os conflitos feriam-se diários, houve dias de mais de um. Holandeses que procuravam faxina ou frutos, destacamentos que pelo istmo saíam de um para outro ponto, caíam em emboscadas que surdiam a cada passo. Trincheiras tomadas a peito descoberto, socorros mandados por terra aos pontos mais afastados, em concorrência com os navios e não raro vencendo-os na rapidez; passagens de rios no momento da maré, para atacar o centro das fortificações inimigas; fome, nudez, falta de pólvora, de médicos e botica, tudo isso de tão comum passava despercebido. Estando, havia quase dois anos, assente na vila de Olinda e povoação do Recife, ainda o invasor não podia, nem o deixava nosso general por si e seus capitães, colher uma só vaca, informa Duarte de Albuquerque. E acrescenta: "Solamente comian de lo que les embiava Olanda; com que bien licitamente se puede decir que sobre estar de tanto tiempo em tierra, aun navegavan, pues no tenian otros bastimentos mas de los salados".

As notícias transmitidas à península não provocaram o alvoroço da tomada da Bahia. Vieram socorros em pequena quantidade, a grandes intervalos e nem sempre aproveitáveis, porque a Companhia dominava no mar, e ora se apossava das caravelas mandadas para Pernambuco, ora as obrigava a vararem em terra, perdendo os carregamentos ou deixando-os a grande distância dos lugares onde faziam falta. Encapava-se esta desídia na corte sob um profundo maquiavelismo: a melhor guerra contra a Companhia das Indias Ocidentais, alegavam estes calculistas insondáveis, consistiam obrigá-la a despesas que com o tempo arrastariam seu descalabro econômico!

Só em 1631 partiu de Lisboa o famoso d. Antônio de Oquendo com uma armada de vinte navios, a 5 de maio. Trazia socorros para Paraíba, Pernambuco e Bahia, e na volta deveria comboiar as embarcações carregadas de açúcar para o Reino. Procurou primeiramente a Bahia, como se quisesse dar tempo de prepararem-se aos holandeses. Estes, apenas souberam da sua vinda, despediram com o mesmo destino uma armada mandada por Adrian Pater.

Deu-se o encontro nas alturas dos Ilhéus, quando Oquendo demandava já Pernambuco, a 12 de setembro; atos de heroísmo houve de parte a parte; o almirante batavo sepultou-se nas ondas com a capitânea; o resultado ficou indeciso, isto é, a Companhia das Índias continuou dominando o mar. Com Oquendo vieram e continuaram no Brasil Duarte de Albuquerque, donatário de Pernambuco, admirável historiador desta guerra, desde o desembarque do Pau-Amarelo até o assalto da Bahia por Nassau (1630-1638), e João Vicente de San Felice, conde de Bagnoli, que já aqui 
estivera com d. Fadrique de Toledo. Depois do combate dos Ilhéus, o inimigo incendiou Olinda, desesperado de fortificá-la eficazmente, e concentrou-se no Recife.

Até aqui sairam frustrados todos os esforços da Companhia para romper o círculo de ferro em que a envolvera Matias de Albuquerque; apenas fundara na ilha de Itamaracá o forte de Orange. Começa agora a sorrir-lhe a sorte. A 20 de abril de 32 passou para seu lado Domingos Fernandes Calabar, mulato natural de Porto Calvo, aonde tinha mãe e alguns parentes. Segundo se pode concluir das poucas e suspeitas notícias encontradas a seu respeito nos escritos contemporâneos, Calabar exercia a profissão de contrabandista, nem de outro modo se podem explicar os roubos feitos à fazenda real de que o acusam os nossos, pois não deviam ter andado dinheiros públicos por suas mãos; para professar o contrabando assinalavam-no a audácia, a presença de espírito, a fertilidade de invenções, o profundo conhecimento das localidades. Era o único homem capaz de se medir com Matias de Albuquerque, e como tinha sobre este a vantagem de dispor do mar, desfechou-lhe os golpes mais certeiros. Qual móvel o levou a abandonar os compatriotas, nunca se saberá; talvez a ambição, ou a esperança de fazer mais rápida carreira entre estranhos, tornando-se pela singularidade de seus talentos indispensável aos novos patrões ou, talvez, o desânimo, a convicção da vitória certa e fácil do invasor.

Entre os feitos mais notáveis inspirados por Calabar contam-se o ataque ao Igaraçu, várias incursões ao rio Formoso, a ocupação de Afogados, séria ameaça ao arraial de Bom-Jesus, entradas por Alagoas, a tomada de Itamaracá e Rio Grande. Estes últimos sucessos deixavam bem iniciada a conquista da Paraíba, agora mera questão de tempo. Em fins de fevereiro de 1634, uma armada para lá se dirigiu, e durante dois dias não cessaram combates; tratava-se, porém, de simples diversão: a verdadeira mira era, como se verificou logo no começo de março, o cabo de Santo Agostinho. Neste porto desembarcavam os socorros vindos da Bahia; ali embarcavam os frutos da terra destinados ao comércio; apossar-se dele era senão impossibilitar de todo, pelo menos paralizar qualquer resistência ulterior.

O inimigo dividiu o ataque em três armadas, uma de treze, outra de onze navios, outra composta de lanchas com mil homens encabeçados por Calabar.
Graças a seu conhecimento da localidade, os holandeses entraram no porto e fortificaram-se no pontal. Um ataque violento dirigido contra eles, e começado sob os melhores auspícios, fracassou devido ao pânico. O arraial passava agora ao segundo plano: heroísmo sobraria sempre ali; o cabo de Santo Agostinho reclamava a efervescência do general. Com os auxílios recebidos de fresco, o inimigo dirigiu-se depois para a Paraíba, sob o comando de Sigismundo von Schkoppe. Governava a praça Antônio de Albuquerque, filho do conquistador do Maranhão, que bem mostrou não desmerecera o sangue paterno. Foi-lhe, porém, impossível impedir o desembarque do inimigo a 4 de dezembro. Os socorros, idos por terra, de Pernambuco, chegaram tarde. Os fortes foram capitulando; véspera de Natal a cidade estava em poder da Companhia. Antônio de Albuquerque ainda tentou fundar um arraial à semelhança do de Bom-Jesus; não encontrou companheiros; os que não se quiseram sujeitar ao domínio estrangeiro emigraram com ele para Pernambuco, e foram batalhar com Matias.

No fim de cinco anos o invasor mandava desde o Rio Grande até o Recife; agora resistiam-lhe apenas o arraial e o forte de Nazaré, no cabo de S. Agostinho. Arciszewski desde Paraíba marchou por terra a apertar o cerco do arraial; Sigismundo von Schkoppe seguiu do Recife para Guararapes a apertar o cerco de Nazaré. Matias de Albuquerque, deixandoo entregue a soldados de confiança, transferiu-se a Serinhaém, para de lá organizar e mandar os socorros. Por terra, por mar, em caravelas, em jangadas, pelos caminhos mais defesos socorreu os companheiros enquanto pode; mas a resistência tem limites. "Afinal faltou o que tudo rende, que é o sustento, e não já de rocins, que isto seria regalo, mas de couros, cachorros e gatos e ratos", escreve Duarte de Albuquerque.

E quando disto houvesse o necessário, já não havia pólvora nem outra munição. Não é de admirar, pois, que se perdesse, não por certo; o admirável é que em tal estado o sustentasse o governador André Marin com seus capitais três meses e três dias.

À rendição do arraial em 3 de junho seguiu-se a do forte de Nazaré a 2 de julho de 1635 .

Al salir nuestra gente cayeron algunos soldados muertos de que parece los sustentava vivos el no moverse. 
Bagnoli tinha-se retirado antes para Alagoas, e Matias de Albuquerque foi reunir-se a ele com duzentos soldados de linha, menos de cem de emboscada e alguns índios. A 3 abalou de Serinhaém este êxodo dos que não desesperavam.

Iam sessenta índios com seus capitães Antônio Cardoso e João de Almeida, ambos bem valentes, descobrindo adiante os caminhos e bosques, por serem nisto tão práticos, como quem havia nascido neles. Seguiam-nos os capitães d. Fernando de la Riba Aguero, Afonso de Albuquerque, d. Pedro Taveira Souto Mayor, Francisco Rabelo, Luiz de Magalhães, Leonardo de Albuquerque.

Logo sucediam os moradores que se iam retirando, e levavam duzentos carros. Atrás destes os capitães Martim Ferreira, João de Magalhães, d. Pedro Marinho, Manuel de Sousa e Abreu, Rodrigo Fernandes, d. Gaspar de Valcáçar e Paulo Vernola. Era retaguarda o capitão-mor dos índios Antônio Filipe Camarão, com oitenta dos seus, armados de mosquetes e arcabuzes.

Confiavam-se a índios os postos de maior perigo! Precisam de outra justificativa os esforços de Nóbrega?

O caminho mais praticável passava em Porto Calvo, ocupado pelo inimigo. Matias de Albuquerque, para facilitar a passagem, teria de atacálo; sua resolução tornou-se inflexível quando soube da chegada de Calabar com um reforço de duzentos soldados. Mandou adiante a gente imbele. $\mathrm{O}$ combate começou a 12 de julho e continuou nos dias seguintes. A 19 o inimigo propôs capitular. Os sitiantes, sem os índios, eram apenas cento e quarenta; o inimigo, além de Picard, chefe holandês, e numerosos oficiais, contava trezentos e sessenta homens. Foram desarmados e logo mandados aos pequenos troços para Alagoas, a fim de não conhecerem a insignificância da força atacante e romperem o pacto à última hora. De todos Matias de Albuquerque reservou para a justiça real o Domingos Fernandes Calabar. No dia 22, "strangulatusque, jugulo defectionem expiavit, et dissectos artus infidelitatis ac miseriae suae testes ad spectaculum reliquit".

Desde muito anunciava-se a chegada de nova e mais forte frota espanhola com socorros. Matias de Albuquerque deixara em diversos pontos do litoral pessoas fiéis incumbidas de darem notícias da terra aos navegantes e fornecerem-lhes indicações sobre o ponto mais convenientes para o desembarque. Devia partir em março, depois em maio, só partiu em 7 de setembro. Reunidos em Cabo Verde os navios espanhóis e portugueses, comandados aqueles por d. Lope de Hoces y Córdoba, estes por d. Rodrigo Lobo, decidiram aproar a Pernambuco.

A 26 de novembro avistaram Olinda, e logo em frente ao Recife surtas nove naus do inimigo, carregadas de açúcar, pau-brasil, tabaco, algodão e gengibre, de partida para a Holanda, cada uma com cinco ou seis homens apenas a bordo. Resolveu-se atacá-las mas o almirante espanhol, a pretexto de suas naus serem maior calado, deu contra-ordem. Nem ao menos se deteve um pouco à espera de algum mensageiro de terra.

Sigismundo ante o aparelho bélico julgou-se perdido, mas a viração soprava de Nordeste, as águas corriam para o Sul, e era agradável entregarse às seduções da corrente. No cabo de S. Agostinho um jangadeiro desfraldando a vela pode comunicar o recado: deitassem a gente no rio Serinhaém, mandassem um navio buscar Matias de Albuquerque! As duas armadas entregaram a solução ao vento e às águas; ao anoitecer de 28 ancoravam em Alagoas.

Vinham a bordo Pedro da Silva, nomeado sucessor de Diogo Luís de Oliveira no governo geral do Brasil, Luis de Rojas y Borja, sucessor de Matias de Albuquerque. Devia este recolher-se ao Reino; Duarte de Albuquerque continuaria no governo político da sua capitania; a Diogo Luís de Oliveira cometia-se a reconquista de Curaçau, antes de voltar para o Reino.

Matias informou largamente a Rojas y Borja do estado de cousas. Em suma, a situação não era desesperada; urgia desandar o caminho percorrido, voltar para o Norte, inquietar, expulsar o inimigo. Calaram estes conselhos: d. Luis pôs-se a caminho de Pernambuco e apossou-se de Porto Calvo, ocupado pelo inimigo apenas os nosso prosseguiram para o Sul, depois da execução de Calabar. Teria forças para continuar as tradições e estaria à altura do seu heroico antecessor? Na batalha de Mata Redonda (18 de janeiro), um mosquetaço na perna derrubou-o do cavalo, outro no peito levou-lhe a vida, aos cinquenta anos de idade. Pelas vias de sucessão assumiu o comando supremo o conde de Bagnoli, velho militar muito difícil de se julgar com justiça. Nossos escritores tratam-no sempre com menosprezo, cobrem-no de apodos, negam-lhe até a virtude elementar da coragem individual. Constitui uma exceção apenas Duarte de Albuquerque, 
sempre discreto e circunspecto, mas sente-se que não expõe todo o seu pensamento. De Bagnoli, se alguma linha já foi publicada relativa ao período holandês, anda perdida em alguma coleção escura: não sabemos como se defenderia dos acusadores. Em todo caso uma honra lhe cabe: nunca desesperou.

Bagnoli assinalou seu comando pelo emprego de companhistas, aventureiros, destemidos, que iam até as barbas do inimigo, aprisionando, degolando gente, jarreteando gado, se não podiam conduzi-lo, queimando os canaviais, os açúcares, o pau-brasil, os engenhos. Alguns avançaram até as fronteiras da Paraíba. Era sempre o pensamento de Matias de Albuquerque: a conquista nunca seria fato consumado. Algum tempo Bagnoli pensou em mover-se para o Norte e fortificou ligeiramente o passo do rio Una, seis léguas ao Sul de Serinhaém. Talvez contribuísse a animá-lo nesta iniciativa tão estranha à sua maneira habitual a presença de Duarte de Albuquerque. Com este avanço os holandeses abandonaram Paripuera e Barra Grande.

Tomado o arraial de Bom-Jesus, ocupada a fortaleza de Nazaré, a Companhia das Índias Ocidentais achou a ocasião própria para nomear um governador geral, como lhe permitia seu regimento.

Escolheu João Maurício, conde de Nassau-Siegen, membro da família de Orange, e confiou-lhe interinamente o cargo por cinco anos. A 27 de janeiro de 1637 aportou Nassau a Pernambuco, onde deveria permanecer um octênio. Em sua companhia ou logo depois vieram consideráveis reforços. Tratou sem demora de retomar Porto Calvo. Do Recife partiram ao mesmo tempo trinta navios com dois mil infantes mandados por Arciszewski, que a 12 de fevereiro fundearam em Barra Grande, e o próprio Nassau com Sigismundo, levando três mil soldados e quinhentos índios, que incólumes passaram o rio Una, já desguarnecido por Bagnoli.

Reunidos apresentaram-se a 17 diante do povoado; a 18 travaram um combate de que a nossa gente não saiu com o melhor partido; a 20 subiram lanchas pelo rio das Pedras, conduzindo artilharia e material; com o canhoneio, respondido sempre galhardamente, baquearam os parapeitos do forte de Porto Calvo, misturando terra nos mantimentos; a 5 de março a falta de víveres obrigou Miguel Giberton, comandante da praça, a render-se.
Na noite de 18 de fevereiro, depois de mandar Alonso Ximénez com parte da força pelo caminho da praia, escoltando a gente que se queria retirar para Alagoas, Bagnoli tomou o mesmo destino pelo interior. A 25 chegava à vila de Madalena, onde não julgou prudente demorar. A 10 de março continuou a marcha e a 17 chegava à vila de S. Francisco, recentemente erigida pelo donatário na margem esquerda do rio, a meia distância entre a barra e a região encachoeirada. Duarte de Albuquerque aconselhou-lhe fortificar-se no rio Piaguí, para resistir ao inimigo, caso avançasse por terra; tão pouca atenção prestou a este como antes ao conselho de fortificar eficazmente o passo da Una. Em ambos os casos o inimigo não deparou tropeços.

A 18 Bagnoli fez os terços napolitano e castelhano atravessarem o rio para a capitania de Sergipe; a 19 passou parte do terço de Portugal, a 26 passou o resto; a 27 chegaram os holandeses à vila e acharam-na vazia. Com a confusão, muitos dos retirantes ficaram prisioneiros, salvaram-se outros perdendo todos os haveres. No local abandonado por Bagnoli resolveu Nassau construir um forte chamado Maurício: lá existe hoje a cidade de Penedo. Sigismundo foi incumbido da construção e do comando. Nassau voltou para Pernambuco.

A 31 de março Bagnoli chegou a S. Cristóvão. Por sua ordem diversos companhistas avançaram para Alagoas, ora acima, ora abaixo do forte, fazendo suas costumadas façanhas. Trouxeram também a notícia de uma invasão planejada no forte Maurício contra Sergipe, no intento de arrebanhar as numerosas manadas de gado, e vingar-se dos audazes que não deixaram os holandeses sossegados em suas novas conquistas. De fato, a 17 de novembro Sigismundo chegou a S. Cristóvão, já deserta, a 25 de dezembro queimou a cidade e retirou-se para o outro lado do rio.

A 14 de novembro, sabendo da entrada do inimigo pelo território sergipano, Bagnoli prosseguiu para a Bahia, com grande pesar e indignação dos emigrados de Paraíba e Pernambuco, que haviam começado suas roças; a 24 alcançou a Torre de Garcia d'Ávilla, onde recebeu ordem do governador geral para se deter. Com alguns companheiros encaminhou-se a 15 de dezembro para a cidade do Salvador a avistar-se com Pedro da Silva, governador geral do Estado. Receoso de próximo ataque dos holandeses contra a capital do Brasil, vinha lembrar a conveniência de estabelecer-se 
com sua gente na antiga povoação de Pereira, onde poderia com suas forças auxiliar a resistência.

Nem Pedro da Silva, nem o povo acreditaram na iminência de tal perigo, ninguém queria a soldadesca na vizinhança. Concordou-se que permaneceriam na Torre e, contrariado embora, Bagnoli submeteu-se. Em breve, porém, seus companhistas trouxeram notícia que Nassau preparava uma expedição destinada a tomar a Bahia e, apesar de pactuado, marchou para Vila-Velha a 14 de março de 1638.

Prisioneiros feitos por Sebastião do Souto, chegados ao acampamento em 8 de abril, dissiparam as últimas dúvidas. A 16 numa forte armada Nassau entrava de fato pela baía de Todos-os-Santos, com três mil e quatrocentos soldados europeus e mil índios, e desembarcou em Itapagipe.

Nos dias seguintes apossou-se de alguns fortes, construiu trincheiras e baluartes, despejou artilharia contra partes da cidade. A continuação correspondeu mal a tão brilhante estreia: as tropas de Bagnoli e a guarnição, deixadas de parte rivalidades mesquinhas, bateram-se com entusiasmo; a população, a princípio tumultuária e desconfiada, acreditou por fim na bravura e capacidade dos defensores; embarcações veleiras traziam sem cessar farinha de Camamu; entrou abundante gado de Itapicuru e do Real; emboscadas repetidas faziam prisioneiros pelos quais se ficava a par de todos os passos do inimigo; realizaram-se sortidas felizes. Na noite de 25 para 26 de maio Maurício de Nassau encerrou as seis semanas de carnificina, embarcando furtivamente para o Recife, não com tanta festa como se prometia, nem com tanto contentamento como desejava.

A vitória foi conhecida na península quando se preparava uma forte armada restauradora, composta de trinta e três navios, comandada por d. Fernando Mascarenhas, conde da Torre. Partiu de Lisboa a 7 de setembro; depois de danosa demora no pestilencial clima do Cabo Verde, passou à vista de Recife em 23 de janeiro de 1639, sem, tão pouco como as duas que a precederam, ousar atacá-lo, e seguiu para a Bahia. Nassau aproveitou o aviso, e no prazo de quase um ano pelo almirante português proporcionado, melhorou as fortificações, organizou um serviço de informações rápidas e aparelhou uma esquadra.
Só a 19 de novembro a armada restauradora partiu da Bahia em demanda do Norte, já então elevada a oitenta e seis embarcações com onze a doze mil homens. A situação de Nassau era aproximadamente a de Matias de Albuquerque dez anos antes, com a grande vantagem de possuir a força naval que faltava àquele.

O conde da Torre poderia desembarcar nas proximidades de Santo Agostinho ou Serinhaém; preferiu abordar o Pau-Amarelo. Não lho permitiu a vigilância do inimigo. Apareceu depois a armada holandesa; entre a ponta de Pedras, o ponto mais oriental do continente americano, e Canhaú, na costa do Rio Grande, renhiram-se combates a 12, 13, 14 e 17 de janeiro de 1640. Apenas cerca de mil soldados nossos lograram tomar terra na ponta do Touro, donde Luiz Barbalho, por entre inimigos e pelo sertão, novo Xenofonte, levou-os heròicamente à Bahia. Já o precedera por via marítima com os destroços que pode salvar o conde da Torre, acompanhado do velho Bagnoli, que não tardou a falecer. O resto da esquadra dispersarase em várias direções.

Os flamengos sofreram grandes perdas; alguns de seus oficiais portaram-se covardemente e foram executados; mas a vitória coube às suas armas e sua posição consolidou-a mais do que nunca.

Podemos deixar em silêncio vários feitos navais dos holandeses e numerosas incursões dos companhistas ocorridos em seguida; outro sucesso reclama de preferência a atenção. A 1 de dezembro de 1640 Portugal declarou-se independente da Espanha, aclamou rei o duque de Bragança, tratou pactos de amizade com os adversários da monarquia espanhola. A 12 de junho de 1641 concluiu com a Holanda um tratado de aliança ofensiva e defensiva na Europa, e nas colônias uma trégua de dez anos, que devia vigorar para os domínios da Companhia das Índias Orientais um ano depois da ratificação do tratado, e nos da companhia das Indias Ocidentais apenas a notícia de haver sido ratificado fosse transmitida oficialmente. Esta cláusula pouco lisa deve ter sido lembrada pelos portugueses, na esperança de melhorarem a situação durante o interstício; de outro modo não se explica terem demorado a ratificação até 18 de novembro. Em fevereiro de 1642 os Estados Gerais ordenaram às duas companhias cumprissem fielmente o pactuado.

Governava na Bahia, como primeiro vice-rei do Brasil, d. Jorge de Mascarenhas, marquês de Montalvão, quando chegou a notícia dos sucessos 
de Portugal. Suas medidas previdentes inutilizaram a pequena guarnição espanhola; todos os magnatas aderiram à independência de Portugal e à aclamação do Bragança, e o resto do país acompanhou-os, mesmo a capitania de S. Vicente, onde havia muitas famílias de estirpe castelhana.

O vice-rei comunicou a novidade a Maurício de Nassau, que a recebeu contente e celebrou-a com festas. O inimigo tradicional era o espanhol; tudo de contrário a este resultava em proveito das Províncias Unidas. As relações melhoraram ainda com a notícia do tratado de 12 de junho; como, porém, a ratificação se demorasse, Maurício ampliou os domínios da Companhia no Maranhão e na África.

Os últimos anos do seu governo cabem em poucas palavras. Da obra do administrador nada sobrevive; seus palácios e jardins consumiram-se na voragem de fogo e sangue dos anos seguintes; suas coleções artísticas enriqueceram vários estabelecimentos da Europa e estão estudando-as os americanistas; os livros de Barlaeus, Piso, Markgraf, devidos a seu mecenato, atingiram uma altura a que nenhuma obra portuguesa ou brasileira se pode comparar, nos tempos coloniais; parece mesmo terem sido pouco lidos no Brasil apesar de escritos em latim, na língua universal da época, tão insignificantes vestígios encontramos deles.

A cidade Mauriceia não guardou seu nome, mas prosperou e conserva sua memória. Com o título de desforra, legado, vingança ou coisa semelhante, de Maurício de Nassau, poderia um amante de fantasias históricas interpretar a guerra dos Mascates adiante narrada, e não precisaria de esforço maior do que o empregado para transformar Domingos Fernandes Calabar em patriota e vidente. A origem principesca de Maurício lisonjeou os colonos e tornou-lhes mais repugnantes os outros governadores, simples burgueses, meros dependentes da Companhia. Ele próprio preveniu disto os sucessores, ao entregar-lhes o mando.

Frei Manuel Calado, que o conheceu e frequentou, apresenta-o como fidalgo de raça, capaz de sentir uma injustiça e repará-la, amante de festas e esplendores, inclinado a farsas nem sempre do gosto mais delicado, admirador das belezas tropicais, isento da preocupação de voltar as terras mais civilizadas. Em limpeza de mãos ficou infinitamente abaixo de Matias de Albuquerque: está provado o seu conluio em contrabandos com Gaspar Dias Ferreira que, como era natural, logrou-o no ajuste das contas, feito em Holanda quando o príncipe já não governava.
À partida de Maurício de Nassau, em maio de 1644, seguem-se dez anos profundamente agitados.

Dos emigrados com Matias de Albuquerque alguns tinham voltado para as antigas propriedades e procuravam reconstituir sua antiga abastança. O regime holandês era duro, as extorsões contínuas; mesmo se Nassau fosse o justiceiro, em que pretendem transfigurá-lo, não tinha braço bastante longo e bastante forte para amparar todas as vítimas.

Os invasores desarmaram a população rural, preferindo deixá-la entregue às devastações inclementes de companhistas a ter de se preocupar algum dia com qualquer tentativa de insurreição.

Como poderia reagir?

O foco do irredentismo, entretanto, lavrava na Bahia.

Norteiros emigrados e reduzidos à miséria, baianos, cujos engenhos devastaram tantas vezes as expedições marítimas dos flamengos, alimentavam profundo rancor contra os seus malfeitores; padres e frades espoliados e expulsos irritavam a consciência religiosa. $O$ sucessor de Montalvão, Antônio Teles da Silva, tão abrasado católico que quis fundar e dotar à sua custa um Santo Ofício para o Brasil, a exemplo de Goa, onde estivera, não podia suportar herejes na vizinhança.

Ainda no tempo de Nassau a religião católica gozava de tolerância embora limitada e instável. Com sua partida, protestantes e judeus ultrajavam a toda hora as crenças da população indígena. Por isso o primeiro título assumido pelos chefes dos insurgentes foi o de governadores da liberdade divina: em linguagem moderna tanto valeria dizer da liberdade de consciência.

Da Bahia devia partir a iniciativa contra o flamengo, pois só de lá podiam sair o armamento, os oficiais, a gente de guerra, em torno da qual se adensassem os pernambucanos bisonhos; precisava-se, entretanto, de um chefe em Pernambuco, para o esforço não ficar perdido nos primórdios.

Um só homem havia ali capaz de assumir esta responsabilidade, se quisesse: João Fernandes Vieira. Natural da ilha da Madeira, passara aos onze anos para aquela capitania, batera-se ao lado de Matias de Albuquerque, e foi um dos prisioneiros do arraial de Bom-Jesus, em junho de 1635. Preferiu ficar com os holandeses, depois da rendição, e a sorte 
protegeu-o. Adquiriu a maior fortuna da terra. Os compatriotas respeitavam-no, e ele os ajudava e protegia liberal e generosamente. Conciliou igualmente as graças dos invasores. Por que artes explica-o no seu testamento:

Também me são devedores [os flamengos]de mais de cem mil cruzados, que no decurso de oito ou nove anos lhes dei por remir minha vexação e por segurar a vida de suas tiranias, de peitas e dádivas a todos os governadores e seus ministros e com grandiosos banquetes que ordinàriamente lhes dava pelos trazer contentes.

À primeira vista ninguém menos próprio para o papel de herói e libertador. Entretanto Vidal de Negreiros, paraibano que começou a se distinguir com Matias de Albuquerque, e oficial da guarnição da Bahia, sondou o espírito de Vieira e achou-o disposto à empresa. Notou, porém, a falta de munições, de armamento, de gente entendida em guerra para $\mathrm{o}$ levante não degenerar em manifestação estéril; para suprir todas estas faltas precisava-se de tempo e de socorros estranhos. De fato foi-se fazendo tudo com as maiores precauções possíveis. Apesar de todas as cautelas, os holandeses tiveram notícias vagas dos preparativos, admira até, que as tivessem tão tarde, quando o segredo andava por tantas bocas, e mandaram duas embaixadas a Antônio Teles, queixando-se dos baianos que fomentavam a revolução nas possessões dos recém-aliados.

Um dos embaixadores, d. von Hoogstraten, comprometeu-se a trair os patrões, entregando o forte de Nazaré de seu comando quando lhe fosse exigido.

Por ocasião da segunda embaixada, Camarão e seus índios, Henrique Dias e seus negros, de acordo com o governador da Bahia, a convite de Vieira tinham passado para o lado de Pernambuco. Peguem-nos e castiguem-nos como merecem, intimava Antônio Teles aos agentes da Companhia das Índias Ocidentais, desde que não pode mais negar a sua ausência. E quando a gente de Vieira começou a se agitar, mandou embarcados dois terços da força paga sob o mando do velho Martim Soares Moreno e do ardente Vidal de Negreiros, a pretexto de conterem os rebeldes. Os dois mestres de campo a 28 de julho de 1645 desembarcaram próximo de Serinhaém; logo a 4 de agosto rendeu-se-lhes o forte holandês ali situado; a 3 de setembro Hoogstraten entregou-lhes o forte de Pontal, como tratara.
Para se ajuizar da importância deste ponto basta lembrar que Matias de Albuquerque nunca mais assistiu no arraial de Bom Jesus depois de tomado o Pontal. Assim a restauração começava por onde findara a conquista. O êxito dos terços baianos seria maior se o flamengo não destruísse a esquadrilha de Serrão de Paiva em que tinham vindo até Serinhaém e se Salvador Correia colaborasse com sua armada, como lhe foi mandado, para fechar o ataque do Recife por terra e por mar.

Desde junho, antes de chegado o reforço da Bahia, a insurreição rebentara em Pernambuco. Com pouca gente, sem armamentos, sem munição, Vieira devia empenhar-se sobretudo em não se encontrar com o inimigo. Isto conseguiu graças às medidas cautelosas anteriormente tomadas, ao requintado serviço de espionagem, apoiado no conhecimento das localidades. Só a 3 de agosto houve o primeiro combate no Monte das Tabocas, e a vitória ficou de nosso lado. Aos que censuram as hesitações de Vieira, suas delongas à espera de Camarão e Henrique Dias, sua insistência por socorros da Bahia, basta lembrar um fato: na batalha das Tabocas muita gente combateu ainda de pau tostado e foice por falta de espingarda.

Uma das vantagens da vitória foi proporcionar armas de fogo e munições tiradas aos inimigos mortos. A tomada da Casa-Forte em 16 de agosto propagou o incêndio. Com a rendição de Serinhaém e do Pontal a Martim Soares e André Vidal, insurgiu-se o Sul até o rio de S. Francisco e a situação voltou ao que era em começos de 1635. As forças baianas, mandadas a pretexto de pacificá-los, reuniam-se sem rebuço aos insurgentes.

Formou-se logo um arraial à margem direita do Capibaribe, e deramlhe o nome de arraial Novo do Bom Jesus. Daqui partiram ataques incessantes contra a gente do Recife. Uma fortaleza no continente, a força do Asseca, sobretudo, causava-lhe grandes estragos. Lembrou-se Sigismundo de repetir a tática pela qual isolara o antigo arraial do forte de Nazaré e obrigara os dois a se renderem. Desta vez o plano mangrou: a batalha dos Guararapes (19 de abril de 1648) terminou em derrota completa dos invasores, que deixaram o campo juncado de mortos e despojos. Uma compensação tiveram valiosa: a devastadora força de Asseca passou para seu poder e em seu poder persistiu até o fim da guerra.

Poucos dias antes da batalha dos Guararapes assumira o comando supremo dos pernambucanos o general Francisco Barreto de Menezes, 
mandado do Reino a este fim. O estado em que achou as cousas descreve assim um historiador destes feitos, arauto enfático de Vieira: "Sem armas e soldados venceu [Vieira] o inimigo que o buscava com soldados e armas na batalha das Tabocas. Depois unido com o mestre de campo André Vidal de Negreiros ganharam a vitória ao flamengo no engenho de d. Ana Pais, e nove fortalezas, com outros redutos e casas fortes; perto de oitenta peças de artilharia de diversos calibres, a maior parte de bronze; armas, munições e petrechos de guerra em tanta quantidade quanta bastou para sustentar a guerra viva em cinco anos contínuos".

À primeira seguiu-se a segunda batalha dos Guararapes, em 19 de fevereiro de 1649, com o mesmo resultado contrário aos flamengos. Depois dela não houve mais combates notáveis por terra nem por mar. A Companhia estava exausta, apesar dos largos subsídios dados pelos Estados Gerais. Dentro em pouco estes não puderam mais auxiliá-la, envolvidos em guerra contra a Inglaterra. Em compensação Portugal organizara uma companhia de comércio que apareceu na costa pernambucana por dezembro de 1653. Os patriotas puseram-se de acordo com ela, como outrora a gente da Bahia com a armada de d. Fadrique de Toledo; o almirante português desembarcou no rio Tapado, o primeiro ponto em que Weerdenburgh tentara o desembarque, e em Olinda combinou com os chefes pernambucanos a marcha a seguir.

Um a um foram caindo os fortes holandeses; a 26 de janeiro de 1654 assinava-se a capitulação da Taborda, e terminava esta guerra, levada quase sem interrupções durante trinta anos.

O desfecho fora previsto e publicado anos antes por Pierre Moreau, natural de Charolais, na Borgonha, que passara algum tempo entre os holandeses, em Pernambuco. Suas palavras patenteiam algumas das mais profundas causas do insucesso final da Companhia das Índias Ocidentais.

\section{"Não há aparência”, publicava em 1651,}

de que os holandeses possam nunca se restabelecer e restaurar no Brasil como eram antes, mesmo se sua frota derrotasse a dos portugueses; mesmo se lhes enviassem outro socorro semelhante ao último, apenas perderiam homens e esgotariam seus tesouros, sem nada adiantar; porque o território que lhes resta desde o Ceará até a cidade de Olinda está inteiramente perdido e sem habitantes, as casas, povoados, aldeias ou vilas, as próprias fruteiras queimadas e arruinadas, portanto seu estado inútil e sem proveito; e embora sejam senhores das fortalezas do Rio Grande e Paraíba, as únicas que resistem com o Recife, para pouco prestam e delas não podem tirar socorros; os que se animam a reconstruir tijupás para cultivar a terra ou se aventuram a alguma distância são surpreendidos e mortos quando menos pensam pelos corsos ordinários dos portugueses, dos Tapuias e dos brasis bravos (desunis) que não têm dó de ninguém.

Os portugueses têm bloqueado o Recife, por terra, de todos os lados, por meio da cidade de Olinda, do cabo de S. Agostinho, das fortalezas construídas em redor; são absolutos por toda a campanha fértil e abundante, e de todas as praças fortes, portos, abras e passagens desde o Recife até a outra extremidade do Brasil além do Rio de Janeiro. Todo o país que possuem é muito bem povoado, com gente de guerra numerosa, sabem subsistir e vivem do que a terra produz com abundância, dispensam facilmente as produções da Europa, coisa impossível aos holandeses, que aliás têm apenas soldados arrebanhados de diversas nações, comprados antes que escolhidos, de cuja fidelidade não podem estar seguros, impróprios aos costumes e ao ar estranho do país, ignorantes dos desvios e das emboscadas dos lugares. Ao passo que os portugueses em sua maioria ali nasceram, dele são originários desde a quarta geração, são robustos, um mesmo povo, dos mesmos costumes e complexões, que se sustentam entre si, não deixam de valorizar e tirar proveito da terra, sabem-lhe até os mínimos recantos, e basta-lhes esperarem os inimigos nas passagens para derrotá-los.

Em outros termos, Holanda e Olinda representavam o mercantilismo e o nacionalismo. Venceu o espírito nacional. Reinóis como Francisco Barreto, ilhéus como Vieira, masombos como André Vidal, índios como Camarão, negros como Henrique Dias, mamalucos, mulatos, caribocas, mestiços de todos os matizes combaterem unânimes pela liberdade divina.

Sob a pressão externa operou-se uma solda, superficial, imperfeita, mas um princípio de solda, entre os diversos elementos étnicos.

Vencedores dos flamengos, que tinham vencido os espanhóis, algum tempo senhores de Portugal, os combatentes de Pernambuco sentiam-se um povo, e um povo de heróis. Nesta convicção os confirmaram os testemunhos do reconhecimento oficial, os encarecimentos dos historiadores, como Manuel Calado e Rafael de Jesus, cujas obras foram logo publicadas, Diogo Lopes de Santiago, inédito até nossos dias, os 
sobreviventes das lutas, os herdeiros das tradições ligeiramente alteradas com o tempo. Um documento de 1703 resume tais sentimentos nos seguintes termos:

Entre todas as nações do orbe são os portugueses os que se têm empenhado nas empresas mais árduas e conseguido os maiores triunfos, tendo pelo mais heroico brasão a fidelidade e íntimo afeto com que não só veneram mas adoram aos seus príncipes naturais: e sendo isto assim parece que em Pernambuco se souberam sinalar com maior ventagem, pois quando mais oprimidos, mais sujeitos e mais desamparados, sem favor e sem humana ajuda, desprezando aquele trato que a continuação de tantos anos pudera por familiar ter facilitado, e mais sabendo grangear os ânimos com liberal mão os holandeses, desprezando tudo com soberano impulso, intentaram e conseguiram a mais ilustre ação e digna de imortal fama, não só porque com invicto sofrimento suportaram o duro peso de toda a guerra, até se extinguir de todo a hostilidade, mas ostentando-se ainda mais generosos, nem um privilégio procuraram impetrar por serviço tão relevante, havendo despendido por consegui-lo todos os seus bens e ficando pobres; e assim sem mais prêmio que o interesse do glorioso nome de leais vassalos, fidelíssimos ao seu rei e amantíssimos de sua pátria, recuperada e isenta de alheio domínio lha restituiram como usurpada, sendo uma tão nobre parte da sua real coroa, a custa do caro preço de tantas vidas e de tanto sangue vertido, recuperando, o que é o mais, o culto ao sagrado que tão profanamente viram da heresia infestado tantos anos.

Passado o primeiro momento de entusiasmo, os reinóis quiseram reassumir a sua atitude de superioridade e proteção. Data daí a irreparável e irreprimível separação entre pernambucanos e portugueses. 